\title{
A Rare Case of Transfusion Transmission of Hepatitis A Virus to Two Patients with Haematological Disease
}

\author{
Suely Gonçalves Cordeiro da Silva ${ }^{a}$ Luciane Almeida Amado Leon ${ }^{b} \quad$ Gilda Alves $^{c}$ \\ Selma Magalhães Brito ${ }^{a}$ Valcieny de Souza Sandes ${ }^{a}$ Magda Maria Adorno Ferreira Lima ${ }^{a}$ \\ Marta Colares Nogueira ${ }^{b}$ Rita de Cássia Barbosa da Silva Tavares ${ }^{b}$ Jane Dobbin $^{d}$ \\ Alexandre Apa ${ }^{\mathrm{c}}$ Vanessa Salete de Paulab Jaqueline Mendes de Oliveira Oliveira ${ }^{\mathrm{b}}$ \\ Marcelo Alves Pinto ${ }^{b}$ Orlando da Costa Ferreira Jr ${ }^{\mathrm{e}}$ lara de Jesus Ferreira Motta ${ }^{a}$ \\ a Serviço de Hemoterapia, HC1, Instituto Nacional de Câncer José Alencar Gomes da Silva, Rio de Janeiro, Brazil;

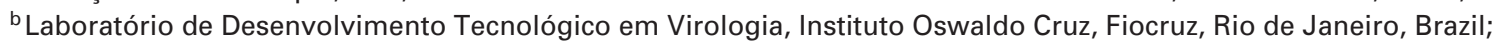 \\ ${ }^{c}$ Coordenação de Pesquisa, Instituto Nacional de Câncer José Alencar Gomes da Silva, Rio de Janeiro, Brazil; \\ dServiço de Hematologia, HC1, Instituto Nacional de Câncer José Alencar Gomes da Silva, Rio de Janeiro, Brazil; \\ e Laboratório de Virologia Molecular, Instituto de Biologia da Universidade Federal do Rio de Janeiro, UFRJ, Rio de Janeiro, Brazil
}

\section{Keywords}

Hepatitis A - Immunosuppression - Window period .

Blood donor · Blood transfusion

\section{Summary}

Background: This paper describes the transmission of hepatitis $A$ virus (HAV) to two blood recipients from a healthy donor that later presented to the blood bank with jaundice. Methods: The RNA of HAV was detected by qualitative nested reverse transcription polymerase chain reaction (nested $R T-P C R$ ) and quantified by realtime RT-PCR. HAV RNA samples were genotyped by direct sequencing of PCR products. A sequence from a fragment of $168 \mathrm{bp}$ from the VP1/2A HAV region was used to construct a phylogenetic tree. Case Report: $A$ 31-year-old male donor accepted for donation of a whole blood unit returned to the blood bank with clinical jaundice 20 days after donation. His serological and NAT tests were negative for HBV and HCV. Serological tests for HAV IgM and IgG were negative on donation sample but positive on follow-up sample, confirming donor's HAV acute infection. Both recipients of red blood cells (R1) and platelet concentrate (R2) from the same implicated donation were HAV IgM-negative and IgG-positive. Qualitative PCR was positive on samples from all three individuals and phylogenetic analysis of viruses proved HAV transmission to the two recipients of blood products. HAV viral load on donor follow-up sample and the platelet recipient was 1.3 and $1.5 \times 10^{3} \mathrm{IU} / \mathrm{ml}$, respectively. The RBC recipient, also infected by $\mathrm{HCV}$, was un- dergoing bone marrow transplantation and died from fulminant hepatitis, 26 days after the implicated HAV transfusion. Conclusion: The blood donor, a garbage collector, spontaneously returned to the blood bank when developing jaundice. This highlights the importance of donor education to immediately report to blood banks of any signs and symptoms related to infectious disease developed after blood donation. The fact that one immunocompromised patient with HCV infection died from fulminant hepatitis after receiving a HAV-contaminated platelet transfusion underpins the importance of a HAV vaccination program for these group of patients.

(c) 2015 S. Karger GmbH, Freiburg

\section{Introduction}

Hepatitis A virus (HAV) is the most common agent causing acute liver disease, with approximately 1.4 million of new cases occurring every year worldwide [1]. In Brazil, two epidemiological scenarios with low and intermediate HAV endemicity are shown. The anti-HAV IgG seroprevalence varies from $33.7 \%$ to $68.8 \%$, for the intermediate and low endemic areas [2]. HAV is a non-enveloped single-stranded RNA picornavirus of the genus Hepatovirus whose most common genotypes found in human infections are the genotypes I and III [1-4]. Most cases of hepatitis A are self-limited and last 2-3 weeks after onset of symptoms [5]. Hepatitis A carries no risk for development of chronic hepatitis.

\section{KARGER \\ Fax +497614520714

(C) 2015 S. Karger GmbH, Freiburg

$1660-3796 / 16 / 0432-0137 \$ 39.50 / 0$ 
The HAV incubation period usually lasts 2-7 weeks (average 28 days) prior to the onset of signs and symptoms. Viremia and fecal shedding often peak 2 weeks before symptoms appear. Laboratory findings are typical of hepatocellular injury with a marked elevated alanine aminotransferase (ALT) that precedes the elevation of serum bilirubin levels by a few days. When symptoms develop, IgM is frequently detected and confirms cases of hepatitis A $[1,5]$.

Usually the main route of transmission is fecal-oral, through contaminated food and water $[1,5]$. Because viremia develops before symptoms onset transfusion transmission by whole blood, fresh-frozen plasma, platelet concentrates, and red blood cells (RBCs) has been sporadically described since 1974 [6-9]. However, in these reports it was difficult to demonstrate direct virological links between blood components and HAV infection.

Using molecular methods, Gowland et al. [10] documented one case of HAV transmission by RBCs to a recipient that was antiHAV IgG-positive. The recipient did not develop hepatitis A but viremia ensued 2.5 months later along with elevation of IgG titer. Sequencing of HAV RNA from both the donor's and recipient's samples confirmed the transfusion link between individuals.

This article describes two cases of HAV transmission by blood transfusion from one infected donor. The two recipients were antiHAV IgG-positive; nevertheless, both developed viremia, and one had elevated liver enzymes and symptoms characteristic of HAV infection. Molecular sequencing of the isolated HAV RNA from the three individuals confirmed the transfusion transmissions of HAV.

\section{Material and Methods}

\section{Ethics}

This investigation was approved by the Ethics Committee of the National Cancer Institute, Rio de Janeiro, Brazil, under the registration number 100/13.

\section{Blood Collection and Manufacturing}

The donor's whole blood was collected on CPDA-1 bag. RBCs and plateletrich plasma were obtained after centrifugation of whole blood within $4 \mathrm{~h}$ of completion of the phlebotomy. The platelet concentrate was prepared by additional heavy-spin centrifugation, followed by removal of supernatant plasma. The platelet concentrate was stored under continuous agitation at a temperature between 20 and $24^{\circ} \mathrm{C}$, and the RBCs were stored at a temperature between 4 and $8{ }^{\circ} \mathrm{C}$. The platelet concentrate was integrated into a pool of platelets that was transfused into a patient (blood recipient R1). The RBC concentrate was filtered and irradiated before transfused into another patient (blood recipient $\mathrm{R} 2$ ). The remaining plasma unit was discarded.

\section{Biochemical Tests}

Testing for alanine aminotransferase (ALT) is not mandatory for blood donor screening in Brazil; thus samples from the implicated donor and blood recipients were referred to the clinical laboratory where serum levels of ALT and total bilirubin were measured on a Roche/Hitachi Cobas 501 analyzer (Roche Diagnostics GmbH, Grenzach-Wyhlen, Germany). The values obtained are within the set limits, according to the manufacturer's instructions.

\section{Serological Assays and Nucleic Acid Test (NAT)}

The presence of anti-HAV IgM and IgG antibodies was investigated in serum samples using a qualitative microparticle chemiluminescence immunoassay on the Architect system Module i2000 (Abbott, North Chicago, IL, USA). In addition to HAV serological assays, blood donor samples were screened for
Trypanosoma cruzi, syphilis, HTLV-1/2, HIV1/2, HCV, and HBV (HBsAg and anti-HBc) by serological assays on the Architect platform and for HIV, HCV, and HBV by NAT performed on minipools of six samples using Cobas TaqScreen MPX test, v2.0 on the Cobas s 201 System (Roche Molecular Diagnostics, Pleasanton, CA, USA). Except for HBV NAT, all assays were mandatory by Brazilian government regulations.

\section{Qualitative Nested RT-PCR}

The viral RNA was extracted from $140 \mu$ of serum using the QIAmp Viral RNA Kit (Qiagen, Valencia, CA, USA). Reverse transcription was performed at $55^{\circ} \mathrm{C}$ for $1 \mathrm{~h}$ using $10 \mu \mathrm{l}$ of RNA, RNasin (30 U/ $\mu \mathrm{l}$ ) (Invitrogen, Carlsbad, CA, USA), random primer $(20 \mathrm{pmol} / \mu \mathrm{l})$ (Invitrogen, Rockville, MD, USA), dNTP (1.25 mmol/l) (Invitrogen, Carlsbad, CA, USA) and Superscript III transcriptase $(200 \mathrm{U} / \mu \mathrm{l})$ (Invitrogen, Carlsbad, CA, USA). The VP1/2A (247 bp) of the HAV genome was amplified using a nested RT-PCR as previously described [11]. The PCR products were loaded onto a $1.5 \%$ agarose gel and stained with ethidium bromide. Fragments of the expected size ( $247 \mathrm{bp}$ ) were purified using the QIAquick PCR purification kit (Qiagen) according to the procedure described by the manufacturer.

\section{Real-Time RT-PCR}

The HAV RNA was quantified from $5 \mu$ of the cDNA with the TaqMan real-time PCR assay using an Applied Biosystems 7500 Real-Time PCR System (Applied Biosystems, Foster City, CA, USA). To quantify HAV RNA, a recombinant clone of the $5^{\prime}$ non-coding region ( 5 ' NCR) of the HAV (strain HAF203) was used as standard curve, and primers specific for the 5 ' NCR of HAV and one HAV probe labeled with 5-carboxyfluorescein were used as described previously [12]. The detection limit reported for this assay was 14 copies $/ \mathrm{ml}$ (3.3 IU/ml) [12]. The viral load results were described as IU/ml, after applying a conversion factor of 4.2 [13].

\section{HAV Sequencing}

HAV RNA samples were genotyped by direct sequencing of PCR products by using internal primers and the ABI PRISM Big Dye Terminator Cycle Sequencing Kit (Applied Biosystems, Foster City, CA, USA) in a Gene Amp PCR System 9700 (Applied Biosystems) [14]. The sequence of 168 bp VP1/2A was used to construct a phylogenetic tree [15]. The HAV genotype is determined by the inclusion of previously published HAV sequences of different genotypes, including genotype strain IA-15, IB strains HM-175 (Australia), and HAF-203 (Brazil), strain IIA SLF88 (Sierra Leone) strain IIB CF-53 (France), and IIIA strain GA76.

\section{Case Report}

The implicated donor is a 31-year-old male accepted for donation of a whole blood unit on December 10, 2011. All his serological screening tests were non-reactive as were the HIV, HCV and HBV NAT. 20 days after donation (on December 30, 2011), he returned to the blood bank service with clinical evidence of jaundice. An investigation of possible transmission of a hepatitis virus was initiated and new sample collected. All donor regulatory screening tests, including HCV and HBV NAT testing, were again non-reactive. As part of the protocol for lookback investigation of transfusion transmission of hepatitis, the serum levels of ALT and total bilirubin were evaluated, and both were elevated $($ ALT $=680 \mathrm{U} / \mathrm{ml}$ and total bilirubin $=7.75 \mathrm{mg} / \mathrm{dl})$. Because the donor is a garbage collector a suspicion of HAV infection was raised, and anti-HAV IgM and IgG antibody tests were carried out and both found reactive.

A sample from the donation day was recovered from the serum repository and tested for anti-HAV IgM and IgG antibodies being non-reactive for both tests. These results characterize an anti-HAV antibody seroconversion confirming the diagnosis of HAV acute infection.

The two recipients of blood components from the same implicated donation have been identified. The first blood component recipient (R1) was a 27-year-old man under chemotherapy for acute myeloid leukemia (AML). He 
Table 1. Laboratory results of samples collected from the implicated donor and blood component recipients ( $\mathrm{R} 1$ and $\mathrm{R} 2$ )

\begin{tabular}{lllllll}
\hline Individual & Tx date & Sample date & Anti-HAV & & HAV NAT Anti-HCV \\
\cline { 3 - 5 } & & & IgM $(\mathrm{s} / \mathrm{c})$ & $\operatorname{IgG}(\mathrm{s} / \mathrm{c})$ & ND \\
\hline Donor & - & December 10, 2011 & NR $(0,23)$ & NR $(0,54)$ & NR \\
& - & December 30, 2011 & R $(12,90)$ & R $(3,95)$ & positive & NR \\
\hline Recipient 1 (PLT) & December 12, 2011 & January 8, 2012 & NR $(0,10)$ & R $(14,71)$ & positive & NR \\
\hline Recipient 2 (RBC) & December 14, 2011 & January 5, 2012 & NR $(0,12)$ & R $(14,34)$ & positive & R \\
\hline
\end{tabular}

${ }^{\mathrm{a}} \mathrm{Tx}=$ Transfusion; $\mathrm{s} / \mathrm{c}=$ sample/cut-off ratio (values above 1,0 is considered reactive); $\mathrm{NR}=$ non-reactive; $\mathrm{ND}=$ not done; $\mathrm{R}=$ reactive; $\mathrm{PLT}=$ platelet concentrate.

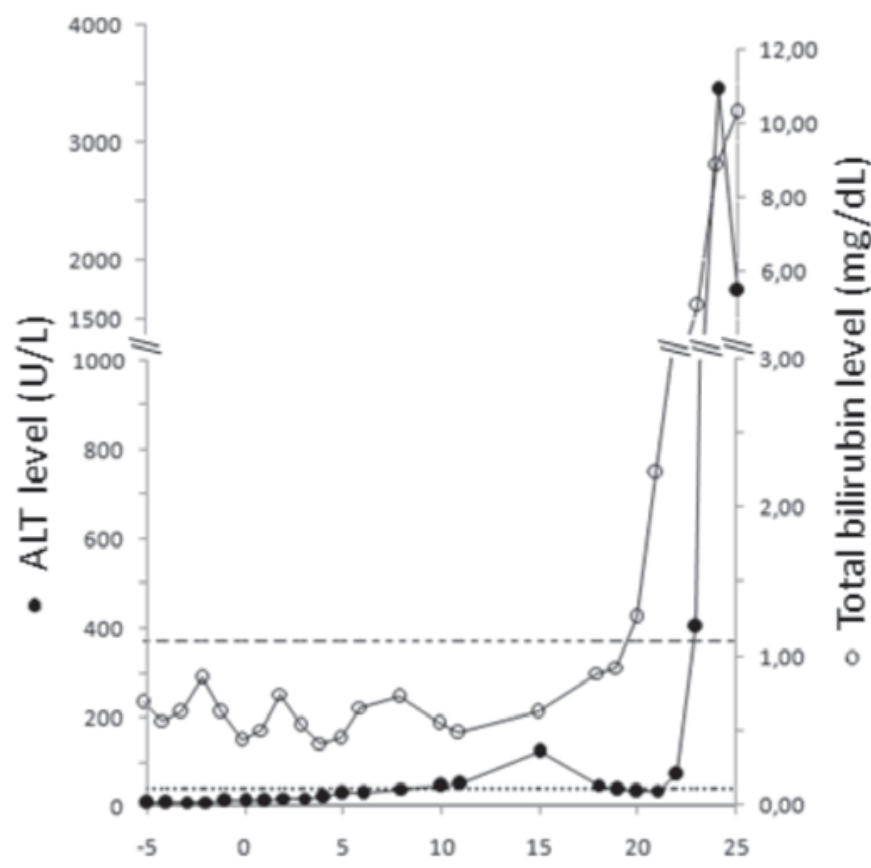

Days since RBC transfusion

Fig. 1. Liver enzymes level of the R2 patient. ALT level (closed circles); ALT reverence level (41 U/l; dotted line); bilirubin levels (open circles); bilirubin reference level ( $1.1 \mathrm{mg} / \mathrm{dl}$, dashed line).

received a transfusion of platelets from the implicated donor on December 12, 2011. His liver enzymes and clinical symptoms were monitored during the 49 days since the platelet transfusion and hospital discharge. During this period he did not show elevated levels of liver enzymes or clinical symptoms of hepatitis. He died on July 2012 of causes related to his underlying disease.

The second blood component recipient (R2) was a 39-year-old man diagnosed with myelodysplastic syndrome, undergoing post-bone marrow transplant immunosuppression and being a chronic carrier of HCV. He received transfusion of RBCs on December 14, 2011, and on January 5, 2012 (22 days after transfusion) serum levels of both ALT and total bilirubin were elevated (fig. 1). The patient died from fulminant hepatitis on January 9, 2012, 26 days after the RBC transfusion. Of note, on the day of his death the HCV viral load was $2.57 \times 10^{6} \mathrm{IU} / \mathrm{ml}$, a value almost 19 times greater than the HCV viral load of $1.36 \times 10^{5} \mathrm{IU} / \mathrm{ml}$ measured on August 2011 .

Serum samples from the two patients collected on January 5, 2012 (R2) and January 8, 2012 (R1) were tested for anti-HAV IgM and IgG (table 1). Sera from both recipients were reactive for anti-HAV IgG but non-reactive for anti-HAV IgM.

These two samples, along with donor's second sample were evaluated by qualitative nested RT-PCR directed to the VP1/2A region (247 bp). All three samples were positive, as shown on figure 2. Furthermore, quantitative real-

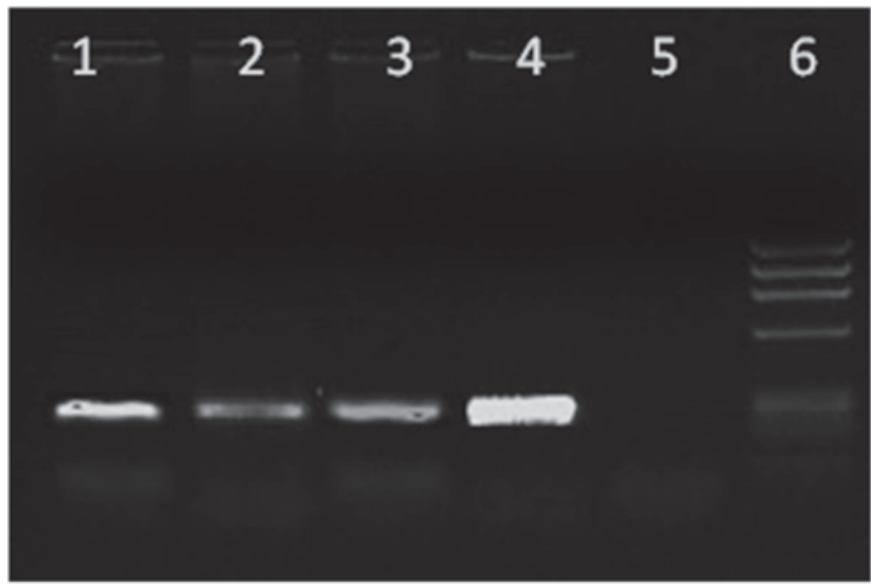

Fig. 2. Detection of HAV RNA (VP1/2A genome). Nested RT-PCR products (247 bp) were visualized by $1.5 \%$ agarose gel and ethidium bromide staining. Lanes: (1) blood donor; (2) platelet recipient (R1); (3) RBC recipient (R2); (4) HAV-positive control; (5) negative control; (6) ØX 174 DNA ladder as molecular size standard.

time RT-PCR was performed on samples from donor (sample from December 30,2011 ) and from platelet recipient with viral load of $1.3 \times 10^{3}$ and $1.5 \times 10^{3}$ $\mathrm{IU} / \mathrm{ml}$, respectively. There was not enough sample volume from R2 patient to perform real-time RT-PCR.

A phylogenetic tree based on 168 nucleotide sequences in the HAV VP1/2A region was constructed (fig. 3). All three viruses sequenced were genotyped as HAV IA. Relatedness between the donor's and recipients' virus sequence was evidenced in this analysis further confirming the HAV transmission by transfusion.

\section{Discussion}

We reported two cases of transmission of HAV via blood transfusion with blood products originated from one blood donor. $\mathrm{He}$ was asymptomatic and anti-HAV IgM- and IgG-negative at the time of donation, but 20 days later, when he returned to the blood bank, he had jaundice as well as elevated levels of ALT and total bilirubin. Moreover, anti-HAV IgM became positive, and viremia $\left(1.3 \times 10^{3} \mathrm{IU} / \mathrm{ml}\right)$ could be detected by PCR. It is likely therefore that blood donation took place during the HAV incubation period.

In adults, HAV infection has an average period of 28 days before symptom onset. In general, viremia precedes peak of liver enzymes by 2 weeks and may last for several months after symptoms disappear [17]. The donor case fitted well with this data. 


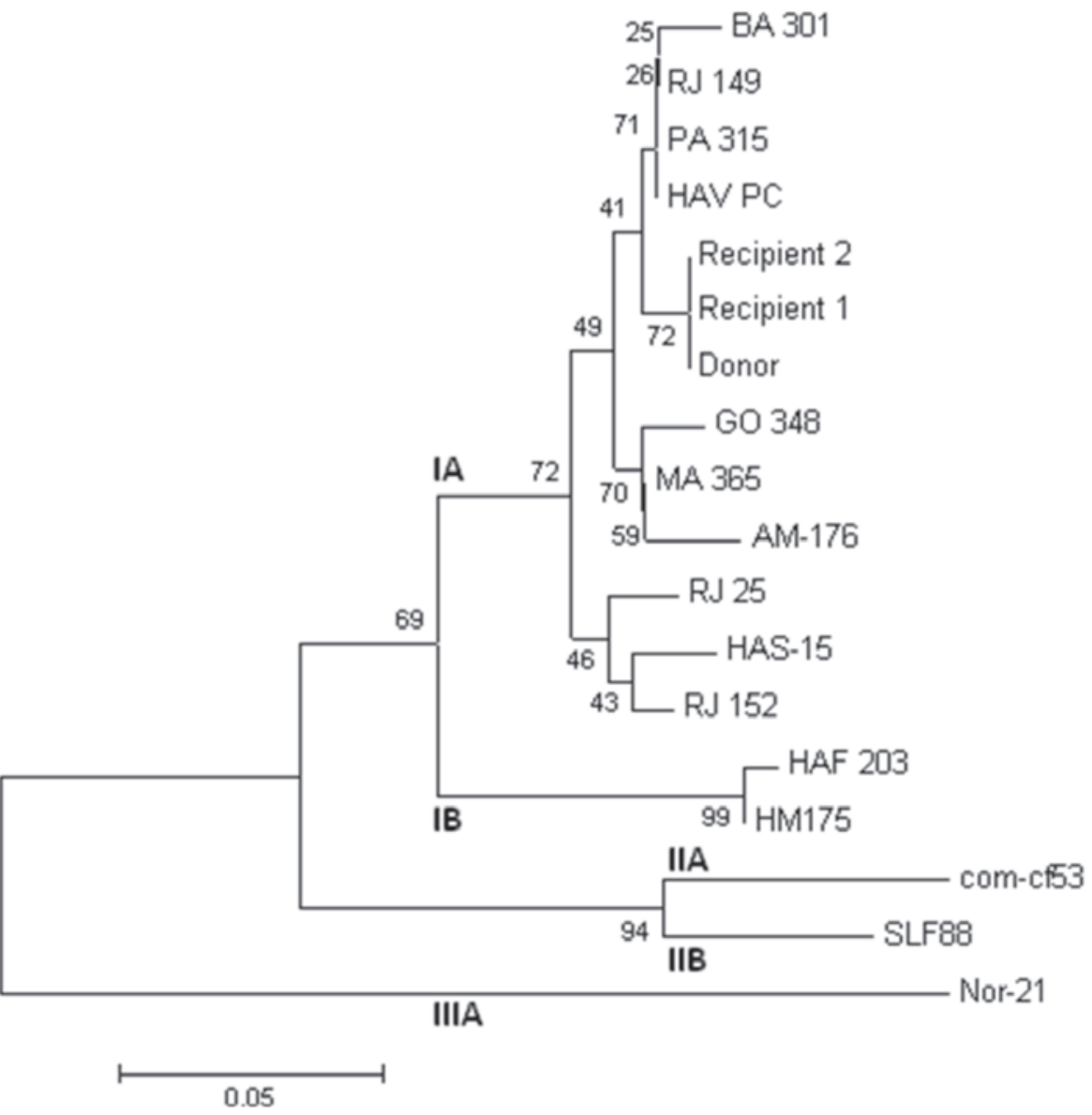

Fig. 3. Phylogenetic tree of the three HAV isolates were constructed by neighbor-joining method and based on HAV 168 nucleotide (positions 3,024 to $3,191)$ in the VP1/2A region. Roman numerals designate the respective genotype groupings, whereas (A) and (B) designate subgenotypes. Bootstrap percentages were calculated from 2,000 replicates. The horizontal bar at the bottom represents an evolutionary distance of 0.05 . Receptor 1 indicates platelet recipient (R1) and receptor 2 indicates $\mathrm{RBC}$ recipient (R2); HAV PC indicates positive control for HAV-nested RT-PCR. References sequences from GenBank included subgenotypes IA: HAS-15 (X15464), IB: HM-175 (M14707, Australia), and HAF-203 (AF26896, Brazil), IIA: CF-53 (L07693, France), IIB: (SLF88), and IIIA: Nor-21 (L07668). The sequences from Brazilian states: RJ (Rio de Janeiro), GO-348 (Goias) (AY322994), PA-315 (Pará) (AY322923), BA-301 (Bahia) (AY322898), has been reported by De Paula et al. [16].

The donor is a garbage collector and may have acquired HAV infection through occupational exposure possibly during collection of contaminated water and/or food. Due to the high risk of occupational exposure to HAV infection, health authorities should reevaluate the standards and encourage the practice of vaccination against hepatitis A for this category of workers.

Although viremia was detected in the two blood transfusion recipients, their clinical courses were very distinctive. R1 died 7 months after blood transfusion of causes unrelated to HAV infection but did not show elevated levels of liver enzymes until 49 days after blood transfusion, when he was discharged from the hospital. It is possible that pre-existing IgG were activated by the infection and partially neutralized the virus, which as a consequence, led to a sub-clinical infection. Corroborating this hypothesis are studies with passive immunization with immunoglobulin that can completely suppress or modify the infection in HAV-susceptible persons depending on the concentration of anti-HAV administered [18]. This case is similar to the one described by Gowland et al. [10] and adds platelets concentrate as source of HAV transmission by transfusion.

R2, however, died 26 days after blood transfusion from fulminant hepatitis, and the level of ALT peaked 2 days before death. Importantly, R2 was under immunosuppressive drugs since before the blood transfusion which may have impaired a normal immune response including IgG burst induced by infection. In this sce- nario, pre-existing anti-HAV IgG may not have been sufficient to completely neutralize the virus. Moreover, R2 had a chronic HCV infection, a condition that when superimposed by HAV infection is associated with a high risk of developing fulminant hepatitis [19, 20], as was the case in this patient.

Timely recognition of post donation symptoms and notification to blood banks is important to limit transmission of infectious agents by transfusion [9]. However, post donation report of donor infection is a procedure which is not clearly defined by blood banks, and as a consequence its communication to the donor at time of donation is often neglected. In this case, and although the blood donor had not been adequately instructed, he voluntarily returned to the blood bank with jaundice. If he had not returned to the blood bank, this lookback investigation would not have been initiated, and a case of HAV transmission by transfusion would have gone unnoticed.

Antibody screening tests for HAV is not recommended for serological screening of blood donors in any country, including Brazil $[21,22]$. In contrast, after a series of reports definitely proving the transmission of HAV by solvent-detergent-treated factor VIII, the plasma industry now tests all source plasma by HAV NAT [23, 24]. However, due to the sporadic nature of the HAV acute infection among blood donors and the lack of HAV chronic carriers the current recommendation for not screening blood donors for HAV seems adequate. 
In USA, the Advisory Committee on Immunization Practices of the Centers for Disease Control and Prevention recommends vaccination of all chronic liver disease patients against HAV [25]. Specific groups of immunocompromised patients, especially those going for bone marrow or solid organ transplantation, may benefit from a HAV vaccination program as well. These are also patients that may need continuous blood transfusion support. The R2 case, therefore, underpins the importance of HAV vaccination in immunocompromised as well as chronically infected HCV and HBV patients.

\section{Disclosure Statement}

The authors declare no conflict of interest.

\section{References}

1 World Health Organization: Hepatitis A. Fact sheet $\mathrm{N}^{\circ} 328$. Updated July 2015. www.who.int/mediacentre/ factsheets/fs328/en/ (last accessed October 26, 2015).

2 Ximenes RA, Martelli CM, Amaku M, Sartori AM, de Soárez PC, Novaes HM, Pereira LM, Moreira RC, Figueiredo GM, de Azevedo RS; Hepatitis Study Group: Modeling the force of infection for hepatitis A in an urban population-based survey: a comparison of transmission patterns in Brazilian macro-regions. PLoS One 2014;20;9:e94622.

3 Cuthbert J: Hepatitis A: old and news. Clin Microbiol Rev 2001;14:38-58.

4 Yokosuka O: Molecular biology of hepatitis A virus: significance of various substitutions in the hepatitis $\mathrm{A}$ virus genome. J Gastroenterol Hepatol 2000;15(suppl): D91-97.

5 Pereira E, Gonçalves C: Hepatitis A. Rev Soc Bras Med Trop 2003;36:387-400.

6 Meyers JD, Huff JC, Holmes KK, Thomas ED, Bryan JA: Parenterally transmitted hepatitis A associated with platelet transfusions. Epidemiologic study of an outbreak in a marrow transplantation center. Ann Intern Med 1974;81:145-151.

7 Skidmore SJ, Boxall EH, Ala F: A case report of posttransfusion hepatitis A. J Med Virol 1982;10:223.

8 Sherertz RJ, Russell BA, Reuman PD: Transmission of hepatitis A by transfusion of blood products. Arch Intern Med 1984;144:1579-1580.

9 Hughes JA, Fontaine MJ, Gonzalez CL, Layon AG, Goodnough LT, Galel, SA: Case report of a transfusion-associated hepatitis A infection. Transfusion 2014;54:2202-2206.

10 Gowland P, Fontana S, Niederhauser C, Taleghani BM: Molecular and serologic tracing of a transfusion-transmitted hepatitis A virus. Transfusion 2004;44:15551561.
11 De Paula VS, Baptista ML, Lampe E, Niel C, Gaspar AM: Characterization of hepatitis A virus isolates from subgenotypes IA and IB in Rio de Janeiro, Brazil. J Med Virol 2002;66:22-27.

12 De Paula VS, Diniz-Mendes L, Villar LM, Luz SL, Silva LA, Jesus MS, da Silva NMVS, Gaspar AMC: Hepatitis A virus in environmental water samples from the Amazon Basin. Water Res 2007;41:1169-1176.

13 Saldanha J, Heath A, Lelie N, Pisani G, Yu MY; Collaborative Study Group: A World Health Organization international standard for hepatitis A virus RNA nucleic acid amplification technology assays. Vox Sang 2005;89:52-58.

14 Otto TD, Vasconcellos EA, Gomes LH, Moreira AS, Degrave WM, Mendonça-Lima L, Alves-Ferreira M: ChromaPipe: a pipeline for analysis, quality control and management for a DNA sequencing facility. Genet Mol Res 2008;7:861-871.

15 Kumar S, Tamura K, Jakobsen IB, Nei M: MEGA2: molecular evolutionary genetics analysis software. Bioinformatics 2001;17:1244-1245.

16 de Paula VS, Lu L, Niel C, Gaspar AM, Robertson BH: Genetic analysis of hepatitis A virus isolates from Brazil. J Med Virol 2004;73:378-383.

17 Bower WA, Nainan OV, Han X, Margolis HS: Duration of viremia in hepatitis A virus infection. J Infect Dis 2000;182:12-17.

18 Hall WT, Madden DL, Mundon FK Brandt DE, Clarke NA: Protective effect of immune serum globulin (ISG) against hepatitis A infection in a natural epidemic. Am J Epidemiol 1977;106:72-75.

19 Vento S, Garofano T, Renzini C, Cainelli F, Casali F, Ghironzi G, Ferraro T, Concia E : Fulminant hepatitis associated with hepatitis A virus superinfection in patients with chronic hepatitis C. N Engl J Med 1998;338: 286-290.
20 Schiodt FV, Atillasoy E, Shakil AO, Schiff ER, Caldwell C, Kowdley KV, Stribling R, Crippin JS, Flamm S, Somberg KA, Rosen H, McCashland TM, Hay JE, Lee WM: Etiology and outcome for 295 patients with acute liver failure in the United States. Liver Transpl Surg 1999;5:29-34.

21 Agência Nacional de Vigilância Sanitária (Brasil). Resolução RDC $n^{\circ}$. 51, de 7 de novembro de 2013. Regulamento Sanitário para Serviços que desenvolvem atividades relacionadas ao ciclo produtivo do sangue humano e componentes e procedimentos transfusionais. Publicada no Diário Oficial da União $n^{\circ}$. 221. Altera a Resolução RDC nº. 57, de 16 de Novembro de 2010.

22 Agência Nacional de Vigilância Sanitária (Brasil). Portaria $n^{\circ} .2 .712$, de 12 de novembro de 2013. Redefine o regulamento técnico de procedimentos hemoterápicos. Diário Oficial da União $n^{\circ}$. 221, de Dezembro de 2010.

23 Mannucci PM, Gdovin S, Gringeri A, Colombo M, Mele A, Schinaia N, Ciavarella N, Emerson SU, Purcell RH: Transmission of hepatitis A to patients with hemophilia by factor VIII concentrates treated with organic solvent and detergent to inactivate viruses. Ann Intern Med 1994;120:1-7.

24 Chudy M, Budek I, Keller-Stanislawski B, McCaustland KA, Neidhold S, Robertson BH, Nubling CM, Seitz R, Lower J: A new cluster of hepatitis A infection in hemophiliacs traced to a contaminated plasma pool. J Med Virol 1999;57:91-99.

25 Prevention of hepatitis A through active or passive immunization: Recommendations of the Advisory Committee on Immunization Practices (ACIP). MMWR Recomm Rep1999;48:1-37. 